\title{
Identity and dignity within the human rights discourse: An anthropological and praxis approach
}

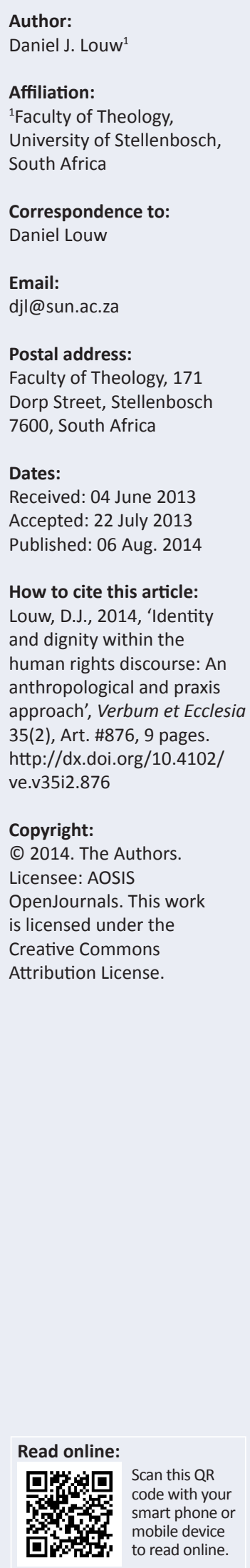

The theological discourse mostly focuses on the moral and ethical framework for human rights and human dignity. In order to give theological justification to the value and dignity of human beings, most theologians point to the imago Dei as theological starting point for the design of an anthropology on human dignity. Within the paradigmatic framework of democracy, human dignity and human rights have become interchangeable concepts. This article aimed to focus not on ethics but on aesthetics: man as homo aestheticus, as well as the praxis question regarding the quality of human dignity within the network of human relationships. It was argued that human dignity is more fundamental than human rights. Dignity as an anthropological construct should not reside in the first place in the imago Dei and its relationship to Christology and incarnation theology. Human dignity, human rights and human identity are embedded in the basic human quest for meaning (teleology). As such, human dignity should, in a practical theological approach to anthropology, be dealt with from the aesthetic perspective of charisma, thus the option for inhabitational theology. As an anthropological category, human dignity should be viewed from the perspective of pneumatology within the networking framework of a 'spiritual humanism'. In this regard, the theology of the Dutch theologian A.A. van Ruler, and especially his seminal 1968 work Ik geloof, should be revisited by a pneumatic anthropology within the parameters of practical theology.

\section{Introduction}

In preparation for this essay, I was so surprised when taking up the work of Ludwig Feuerbach (1904) on the essence of the Christian faith: Das Wesen des Christentums, to discover his struggle to free traditional, and therefore 'orthodox theology', from its God-ideology and to turn theological reflection to the praxis issues of life, to the meaning of our being human within social contexts. He called this focal point: the wellbeing (heil) of humans (Feuerbach 1904:283). To my mind, the latter should be the focal point in a practical theological approach to the human quest for meaning and dignity. To what extent is the quest for human dignity, human rights and human wellbeing a practical theological question? Or does this question point merely to 'humanism'?

The August-October 2012 mine strikes in South Africa put anew the question regarding the relationship between human dignity and human rights on the agenda of the human rights discourse. On 02 October 2012 there were pictures of violent people on television using the slogan: 'We demand our right to human dignity.' The next day in the newspaper in a report on crime in the Cape Flats, it was pointed out that gangsters claim it as their right to point guns at the police. From the viewpoint of the politicians, the approach was to warn the police against force and to care for the dignity of the gangsters. From an ethical point of view, some politicians argued that police should not defend themselves with guns. In the meantime, a child of 6 years, Leeana van Wyk, was severely wounded by the shooting of the gangsters. The mine strikers also killed two policemen; 3 days later, police opened fire on a group of protesting miners, some of whom were armed, and 34 strikers were killed. Elsewhere, in the name of workers' rights, striking truck drivers set 17 trucks on fire. Some of the drivers were severely wounded and ended up in hospital, and all in the name of democracy and human rights. ${ }^{1}$

Is it possible to demand human dignity as a right? Although human dignity and human rights are closely connected (they are to a large extent interconnected), the basic assumption is that human dignity is a spiritual concept. It points to the quality and value of our being human within the dynamics of relationships. As a spiritual category, human dignity, within the framework of a theological anthropology, is a category sui generis. The quest for dignity is a teleological issue; it is fundamentally about the significance of human life (acknowledgement and fulfilment) and an understanding regarding the beauty of life and the aesthetics of being human. Thus the remark of Valadier (2003:50): dignity 'presupposes a whole anthropology'. 


\section{The praxis question: Happy Sindane and the human quest for identity and dignity}

With praxis is meant: the intention of human actions within the dynamics of human relationships. One can call it the intentionality within practical actions; that is, the teleological dimension of practical theological reflection. Praxis describes the qualitative dimension of being functions and is therefore directly connected to the anthropological quest for meaning, dignity and identity. Praxis refers to habitus, which is attitude and aptitude as indicators of the ontological quality of our beings functions.

In the 1980s, Ed Fairley (1983:23) already advocated for practical theology as the engagement with habitus; habitus as a disposition and motivational power within the actions of the human soul. The whole of the ministerial praxis is determined by disposition emanating from the notion of salvation (our eschatological identity). Disposition is an ontological category representing a new state of being and the stance of our being human in the presence of God. Thus Fairley's (1983:31) argument to move from the clerical paradigm for ministry into the habitus-paradigm: "The term "practical theology" occurred originally to describe theology/habitus.' As such, 'practice meant that aspect of the habitus or wisdom in which the divine object sets requirements of obedience and life' (Fairley 1983:27).

Habitus, as an anthropological category, is intrinsically an aesthetic category (Fairley 2001) referring to the quality of human identity and human dignity. The following case of Happy Sindane poses, to my mind, the praxis question regarding the value of human life and the aesthetics of being functions. ${ }^{2}$ It reveals the fact that identity is more basic than rights. Happy Sindane was born to a White father and a Xhosa mother in 1984. Very little is known about his father, Henry Nick (German), who was his late mother's employer. Sindane was thrown into the spotlight in 2003 when he claimed to be a White boy who had been kidnapped by Black people. In 2003, he walked into a police station and told the bemused cops that he was a 16-year-old White boy who had been kidnapped and then raised by a Black family. His quest was quite simple: he wanted to find his true family, to be returned to them, to reclaim his rightful childhood which was stolen from him. It was found by the court that Sindane's claim was a kind of 'lie' in order to find identity. It was described by the ruling magistrate as an 'intentional lie', a kind of provisional truth that was emotionally and psychically necessary, even though it might not have been factual. This 'intentional lie' masked a child's refusal to accept his father's absolute rejection and his mother's disappearance. The lie was a kind of survival strategy in his desperate attempt to gain identity. After DNA tests, he was identified as Abbey Mzayiya, the son of a domestic worker, but chose to use the name Happy Sindane.

2.All information provided in this case study was compiled by the author in the light of news reports on television and different daily newspapers.
Sindane made news headlines again in 2013 when his body was found in a ditch early on Monday morning 01 April, less than $2 \mathrm{~km}$ from his home. A passer-by found his battered body lying on a rocky, litter-strewn piece of veld in Tweefontein, Mpumalanga. He had been stoned to death. There had allegedly been an altercation over a bottle of brandy at the JZee tavern where Sindane had been drinking. An empty bottle was found near his body. The 58-year-old man with whom Sindane had been reportedly fighting in the tavern was subsequently arrested in connection with Sindane's murder.

Sindane's biological siblings, the Mzayiyas of Diepsloot in Johannesburg, who requested to have him buried next to his mother in the Eastern Cape, did not attend the funeral because they were not consulted about funeral arrangements. The real tragedy regarding the death of Sindane is that he died even before he was murdered. His life was taken from him due to a loss of love and a confused sense of identity. The loss of identity 'killed' him; one can even say that the fear for rejection without an intimate space to be accepted unconditionally for who he was, was the real cause of his 'death'. A human being without identity and dignity becomes a 'thing' and mere 'commodity'. At his funeral, Sindane's grandmother, Johanna Masombuka, covered his coffin with a large blanket, a ritual performed in Ndebele culture. Magistrate Marthinus Kruger, who had presided over Sindane's custody matter in 2004, conducted the service, reading from Psalm 23.

In the majority of news reports about the events described above, it seemed that the focal point in the public discourse was the rights of Happy Sindane, but who cared for the dignity or beauty of Happy Sindane? Is the quest and demand for human rights perhaps not fundamentally linked to a qualitative question: what is the character of a human being's dignity and identity?

\section{Human rights: A luxury within the hell of slums?}

It seems that within poor communities in Africa, the discourse on human rights is, to a large extent, a luxury. The basic praxis question is how to survive and not to lose your human dignity. Zanotelli (2002:13-15), in the publication The slums, describes the slums of Nairobi as the hell of life. The slums are usually placed below the sewer line. Within this environment, in order to pose the above question on human dignity, you first need to wash away your materialism, rationalism and 'baroque Catholicism' (Zanotelli 2002:15). The next step is to descend into the hell of the slums; you need to undergo the baptism of the poor in order to talk about dignity:

You learn to read things upside down. Your worldview, your theology, even your morality, just goes to pieces. When I try to dissuade young girls from going to town for prostitution they tell me there is no other way to survive. 'But you are sure to meet Aids!' I insist, 'It's OK! Die of Aids or die of hunger, what's the 
difference? Or maybe there is! You have a chance of longer life with Aids'. I understood that what I held as morality is, to a large extent, middle class morality. (Zanotelli 2002:14)

\section{Problem identification}

Owing to the democratic ideal, Christian spirituality has been hijacked by political democratisation. It is indeed true: dignity (spiritual realm) and rights (political realm) complement each other. They complement each other because Christianity provides a spiritual foundation for the democratic principles of equality and liberty, whilst democracy offers a practical system of government that suits Christian 'concerns for human dignity and depravity' (Kraynak 2003:105). Although complementary, spirituality (Varga 2007:157) is more fundamental; it makes life sacred and open to the individual (Berger, in Giorgian 2007:170).

The challenge to a theological anthropology is to describe the dynamics between dignity and meaning within the parameters of a spiritual hermeneutics in order to understand better how, eventually, identity is related to human dignity and the spiritual quest for meaning and destiny. Meaning is spiritual and, according to Gräb (2006:52), an indication of meaningful self-expression (Selbstdeutung); meaning and destiny then not in the sense of a fixed purpose-driven agenda, but an understanding of the quality of life in order to create a humane, safe environment and space for human interaction. According to Flory and Miller (2007:201-218) 'expressive communalism' displays a kind of immediate artistic expression of meaningful living, what one can call an 'embodied spirituality'. In order to do this, the notion of aesthetics should be first on the agenda of human dignity and processes of democratisation.

Within a context of living below the sewer line, social violence, crime and fraud, the relationship between human rights and human dignity indeed become a burning issue. Should human rights be founded in human dignity and not vice versa? If one is deprived of all forms of human rights, can human dignity still prevail, as in the case of Happy Sindane?

\section{Hypothesis}

My basic hypothesis is that in order to detect the meaning of identity and dignity, and to promote human rights, our starting point in the first place should be aesthetics (with the emphasis on the value and meaning of human life) and not ethics (with the emphasis on moral issues and the tension between good and evil). When one starts with human rights, the discourse runs the danger of becoming moralistic in the sense of conditional demands (a moralistic imperative). Hobbes' 'wolf' then dictates the claim for human rights. However, human beings should be assessed in the first place within aesthetics categories (the indicative of being) and not from the perspective of ethical categories (the imperative of being as related to morality and sinfulness). Theology is basically a reflection on the 'Divine Beauty' (Pattison 2008:109-110); theological ethics emanates from theological aesthetics (Murphy 2008:5).
My second hypothesis is that dignity is not a value inherent in the person (Hobbes, in Negt 2003:30); dignity is a relational category:

So dignity is not an attribute peculiar to persons and their singularity; it is a relationship, or rather manifests itself in the gesture by which we relate to others to consider them human, just as human as we are, even if their appearance suggests nonhumanity, indeed inhumanity. (Valadier 2003:55)

I cannot 'claim' dignity; I am dignity and dignify life within the quality of habitus.

\section{Homo aestheticus: Eschatology and the beautification of human life}

Within traditional Christianity, the notion of 'beauty' is often absent in theological reflection (Fairley 2001:6); rather, there is a kind of indifference which treats beauty as the beast, something to be excluded, marginalised or ignored (Fairley 2001:7). In systematic theology, human dignity is mostly viewed as an ethical issue and not as an aesthetic issue. For example, Huber (1996:xvi) links human dignity and human rights to an 'ethics of human dignity'. Indeed, 'Human dignity is a packed-up ethical argument. Its lofty status can be recognized from the way in which it is written into the texts of constitutions' (Ammicht-Quinn 2003:39). Perhaps, the reason why the discourse on human rights mostly focuses on dignity as an ethical category is the close connection between dignity and human failure (sinfulness).

In the debate on a theological approach to anthropology, theologians usually point very aptly to the notion of human sin and the connection between the corruptio totalis and human fallibility. In many cases, the reason why Christian spirituality was hesitant to be engaged in the debate on human dignity and human rights, was the use of the notion of the Fall as the starting point for a theological reflection on anthropology. For example, the anthropological notion of creation and the 'image of God' stir up the debate on the doctrine of sin. Hence, the shift in many 'enlightened' theological circles on human rights to withdraw from the doctrine of original sin:

The more uninhibited and optimistic the talk was regarding the dignity and abilities of humans, the greater was the need to relativize and secularize the doctrine of original sin. The doctrine appears - in the form of insight into the finiteness and fallibility of humans - merely as a limiting condition of human self-realization, no longer a description of the very essence of humans. (Huber 1996:120)

Theological aesthetics does not ignore the reality of human fallibility, but rather takes as its starting point the exclamation of God that the creation of humans was an aesthetic event and regarded in the Genesis narrative as excellent and 'very good'. Good then not as an ethical category, but as a meaning category detecting destiny, significance and purposefulness (telos), as well as an aesthetic category pointing to worth and vocation. Theological aesthetics deals with the quality and value of our being functions and eschatological status before God (coram Deo). 
In this respect the notion of ethos is most helpful. Ethos refers to virtue and attitude, conduct and habitus, the essential make-up and characteristics of something (human identity). Ethos refers to the aesthetics of identity and dignity. In this case identity represents the unique personal, individual characteristics of a human being (our calling and vocation), whilst dignity reflects personal self-value and self-image as related to meaning and worth.

Aesthetics without ethics is not possible. Whilst ethos is connected to the aesthetics of value and meaning, ethics represents the normative framework of life; it gives direction to ethos and represents the imperative within the indicative of aesthetics. Ethics represents the normative framework for meaningful living. However, being and the mode of human existence (So-sein) are, in a spiritual approach to anthropology, more fundamental than doing. The argument of Drewermann (1992) points in the same direction. Being, and the identity-question 'Who am I?' are more fundamental than the question 'What should I do?'. Inner truth and knowledge have priority over behaviour and external actions (Drewermann 1992:755). The task of hermeneutics is to bring the deeper levels of existential anxiety to consciousness and to peace (Drewermann 1991:339). If it fails to do this, a hermeneutics of human self-understanding faces the danger of becoming merely a process of moralising.

What then is 'human' in human dignity and human rights, especially if one takes Hobbes' notion about the wolf in human nature seriously: homo homini lupus (Negt 2003:31)? What then is meant by human dignity in a theological anthropology and the meaning of life? What is the link between human dignity and the notion of a Christian spiritual aesthetics?

\section{Dignity and beauty from the perspective of eschatology}

From a judicial point of view, dignity is mostly associated with equality, human rights and the value of people. With reference to Kant (in Ackermann 2013:58), one can argue that dignity refers to autonomy or freedom. Thus, the hypothesis of Ackermann (2013:85) is that dignity connects with concepts such as equality and non-discrimination. In this regard human worth (dignity) becomes a kind of criterion in order to detect respect, non-discrimination and equality.

As stated above, in the debate on the interplay between human dignity and human rights, the main starting point for theological reflection is mostly creation and the notion of the image of God. For example, the Italian humanism of the 15th century built the notion of human dignity upon the concept of humans created in the image of God (Huber 1996:117). However, the 'image of God' concept in Genesis 1:26 points more to qualitative representation within the dynamics of relationships than to rights, ethics and morality (AmmichtQuinn 2003:41).

What it means to be truly human is closely connected to the fact that human beings live in the presence of God and are created in the image of God to present the character and identity emanating from the covenantal encounter with God. Despite the close identification between dignity and rights in the anthropological approach of J. Moltmann (1984:23), the following quotation underlines the notion of representation within the dynamics of relationships: 'The image of God is human rights in all their relationships in life.' Thus in God's liberating and redeeming action the original destiny of human beings is both experienced and fulfilled. In the 'image of God' concept, the divine claim upon human beings is expressed (Moltmann 1984:22).

According to Kraynak (2003:90), the problem with the notion of the imago Dei resides in the fundamental difference between the biblical and the contemporary understanding of human dignity: 'In the biblical view, dignity is hierarchical and comparative; in the modern, it is democratic and absolute.' A further problem is that the imago Dei refers not so much to inherent dignity, but to representation. It is more a relational category; 'it is also something to be won or lost, merited of forfeited, augmented or diminished' (Kraynak 2003:91).

Owing to the emphasis on aesthetics rather than ethics, our point of departure is not the creation paradigm but the recreational paradigm of eschatological thinking. Eschatology and its emphasis on justification views human beings from the perspective of who we already are in Christ (spiritual ontology). Our identity is determined by salvation and grace. We are accepted unconditionally for who we are. It is not what we do that is fundamental for the quality of ethos, but who we are. The indicative of salvation determines the imperative, which emanates from the eschatological character of salvation. 'The imperative does not appeal to Christian's good will or ability, but recalls what they have already received in baptism: freedom and a new Lord [the indicative]' (Schrage 1988:176). What is therefore required is not that we do something, but that we be something (some-body) (Schrage 1988:43). The crucial point is the transformation and metanoia of the individual (transformation of stance, conduct and orientation, the telos of life) in terms of intention, motivation and goal. Thus, Schrage's conclusion is that Jesus' ethics was an ethics of intention (Schrage 1988:43).

The salvific nature of the kingdom of God determines our ontological stance in both life and death. The character of the kingdom determines human conduct (Schrage 1988:37). This character of the kingdom can be captured by the theological notion of eschatology. Because of eschatology, the will of God cannot be deduced from any universally recognised ontological order as in the case of the so-called ethics of natural law. The status quo cannot be preserved as in the case of the doctrine of creation in ethics. God's will is enacted in the eschatological act of salvation.

The important point to grasp in an eschatological approach is that human conduct (habitus) is a consequence, not a condition, of parousia. Within the coming of God's kingdom, this eschatological stance and understanding of consequential pneumatological action is the impetus for meaning. When 
we do not cooperate and embody this eschatological and pneumatological realm, the indicative of salvation becomes judgement.

Ethics is a consequence of eschatology and not a precondition. In this way an eschatological approach undermines perfectionism and legalism. What is most needed is wisdom (sapientia) in order to beautify human life; the aesthetic presence of unconditional love: 'Presence embodies grace' (Augsburger 1986:36).

Within a pneumatological paradigm, the human being is not assessed in terms of an opportunistic approach, which implies that all relationships are fine when they only embody God's presence through empathetic responses. In an opportunistic approach the focal point is merely individual need satisfaction and the maintenance of basic human rights. Neither are humans assessed in terms of a pessimistic approach, which implies that human beings are merely sinners and doomed to failure. In a pneumatological approach, human beings are assessed realistically. A realistic approach in spirituality means that as Christians we are already new beings in Christ. In Christ, humans are endowed with the fruits of the Spirit (Gl 6:22-26). Human beings in Christ are 'charismatic human beings'. The reality of the fruit of the Spirit implies a pneumatological ontology: one is (eschatological speaking) therefore love. From a pneumatological point of view, love - as in the case of all the fruit of the Spirit - is now a being function and aesthetic category. 'Do you not know that your body is a temple of the Holy Spirit, who is in you, whom you have received from God?' (1 Cor 6:19).

Eschatological aesthetics provides the driving and motivational factor for human actions. Eschatology and its connection to the theological notion of grace provide the spiritual, even psychic energy for meaningful living. For Rombach (1987:379), dignity then describes the humane human being (Der menschliche Mensch); the human being shaped by the social processes of identity and meaningful space (Identität $=$ a spiritual networking of meaning as the whole which gives significance to every particular part).

\section{From human rights to human dignity (dignitas)

Purposefulness as an aesthetic taxonomy of
human life

To a certain extent the concepts of human dignity and the notion of the democratisation of life have become closely linked to the notion of human rights. According to Huber (1996:114), ideas of human dignity and human rights have been shaped by a long historical development. In this regard respect and equality are interconnected categories.

Within the European tradition, talk of human dignity was intertwined with the rank and status of particular persons in society. The concept dignity (dignitas) is therefore a social category related to that of honour (honor) (Huber 1996:115). The turn toward the human being as the centrum of the whole of the cosmos was fed by the renaissance and the humanism of the Enlightenment. Owing to the Kantian influence of human beings as rational beings, the notion of human autonomy put an 'anthropocentric' worldview in the centre of the human dignity debate. Within this worldview 'dignity' has increasingly meant 'the worth of being human':

Dignitas became closely associated with humanitas as to be construed as a synonym. To be able to say what dignity is would be to describe the fundamental meaning of being human. (Meeks 1984:ix)

Dignity means to be human. 'For this reason, dignity has become the key concept in the worldwide struggle for human rights' (Meeks 1984:ix).

Within the human rights discourse it is often extremely difficult to differentiate between human rights and human dignity. The discourse has become 'slippery'. Human dignity has even become an in-between issue; it is squeezed in between sanctity and depravity (Witte 2003:119-137), between man as beast and man as an angel (merely divine) (Meilaender 2009). Mostly, the debate focuses on moral and democratic issues within the framework of personal, social and political ethics. Moltmann (1984) distinguishes between human rights as the quest for freedom, justice and equality, whilst dignity refers to how these issues impact on the quality of life of the individual, the unique and particular person:

Human rights are plural, but human dignity exists only in the singular ... The dignity of humanity is the only indivisible, in alienable, and shared quality of the human being. (Moltmann 1984:9)

Initially, European humanism linked the notion of human dignity to the Christian concept of humans created in the image of God. Human beings became the microcosm of God, containing in them a multitude of choices. One can therefore say that the 'modern age, which began with humanism, is characterized by the conviction that human dignity is anchored in the self, namely in one's rational talents' (Huber 1996:117). It was when the recognition of equal dignity of all human beings was incorporated within the politics of democratisation and institutionalised by international law that the shift from dignity to human rights became a focal point for the discourse on the value and worth of human beings. The reason perhaps is that human dignity, however, requires human rights for its embodiment, protection and full flowering (Meeks 1984:xi). One must therefore admit that without human rights human dignity becomes a fleeting idea without concrete and contextual meaning.

Within the tradition of Plato, Aristotle and Kant, dignity became mostly related to intelligibility. Dignity then resides in the human nous or mind. Eventually dignity and rights become qualities of radical rational autonomy:

On one common reading, 'dignity' refers to a basic faculty; it denotes the bare capacity for intelligent free choice shared 
equally by all non-damaged persons. One's rational freedom may be misused, but the simple possession of it is the ground of respect. (Jackson 2003:143)

Meilaender (2009:8) distinguishes between two concepts of dignity: human and personal. Human dignity then has to do with the powers and the limits characteristic of our species a species marked by the integrated functioning of body and spirit. Personal dignity refers to the individual person whose dignity calls for our respect whatever his or her powers and limits may be. Although human dignity refers to many layers of meaning, Meilaender (2009:89) points to equal respect as a principle and theoretical basis for human dignity.

Albeit, one should agree with Meeks (in Moltmann 1984:ix) that 'dignity' is a difficult word to define. It is often used as an exchangeable concept for human rights. 'For this reason, dignity has become the key concept in the worldwide struggle for human rights' (Meeks, in Moltmann 1984:ix), a struggle embedded in different cultural contexts and deep ideological disagreements over human rights. The further problem is that dignity defined in many different ways immediately entails a counter-definition of others as inhuman, not possessing dignity.

In his book On human dignity, Moltmann (1984:31) also connects the two concepts to one another: 'Through the service of reconciliation, human dignity and right are restored in this inhuman world.' However, the important point in the human rights debate is that human dignity determines the quality of human rights; hence, the reason to separate the two in order to understand their interconnectedness. 'Human rights spring from human dignity and not vice versa' (Meeks 1984:xi). Furthermore, one can conclude and say: human rights presuppose a kind of fundamental dignity and therefore a sense of meaning, purposefulness and vocation. However, human dignity as a sense of meaning and vocation has implications for the quality of being functions. Its link with responsibility and purposeful actions presupposes definite personal qualities and character. This is where the interconnectedness between identity, dignity and virtues come into play.

\section{Virtues and meaningful actions}

Kreeft (1986:192) argues that virtue is necessary for the survival of civilisation, whilst religion is necessary for the survival of virtue. Without moral excellence, right living, goodness, purity, chastity and effectiveness, our civilisation is on the road to decline. Civilisation needs justice, wisdom, courage and temperance.

It was Aristotle who underlined the importance of virtues for purposeful actions. To this end he identified four basic virtues - prudence, justice, temperance and courage. It is indeed true that Aristotle and Homer's understanding of arete differs from that of the New Testament. The New Testament not only promotes virtues such as faith, hope and love, but views humility (the moral for slaves) as one of the cornerstones in the formation of a Christian character (MacIntyre 1984:245). MacIntyre's (1984:249) conclusion is of importance to the debate on the interplay of values and virtues. In both the New Testament and Aristotle's comprehension, despite differences, virtue has this in common: it empowers a person to attain that characteristic essential for attaining meaning and significance (telos).

Virtues motivate people and bring about integrity (Crossin 1998). They represent enthusiasm for life (enthusiasm = literally, God within us) and become a driving force that enables one to establish and nurture life-giving and healthy relationships. They safeguard human dignity and bring about a human space of moral soulfulness. Sound values are part and parcel of spiritual health; vice points in the direction of spiritual pathology and 'moral illness'. Virtues could be viewed as identity made visible in habitus and the quality of human relationships. Virtues display identity (Meilaender 1984) and reveal the character of our being functions; they exhibit the character of the human soul and are tested and displayed within the realm of relationships.

\section{Human dignity and human identity: Towards a relational approach}

The argument up to now has been that identity is a qualitative concept and connected to the value of inter-human and intra-human communication. Human dignity and human identity should therefore be viewed as relational categories. Relation refers to intimacy and interconnectedness; it can, inter alia within the framework of African spirituality, be linked to a kind of ubuntu-philosophy, namely that a human being is only humane through the relationship with another human beings. What is envisaged in an African spirituality is harmony in interpersonal relationships: umuntu ungumuntu ngabantu or motho ke motho ka batho - approximately translated as: 'a person is a person through other people' (Mtetwa 1996:24). Life can therefore only be healed if relationships are healed.

It is a fact that the notion of relationality was often questioned as a reliable and valid approach. The critical point is then that human beings often act in relationships with enmity, hatred, anger and violence rather than with unconditional love. Our love is most of times conditional. Hobbes' terse slogan that man is wolf to man (homo homini lupus) is from a sociological point of view indeed relevant. However, it is argued here that from a pneumatological point of view, theology should revisit the slogan: 'man is man to man' (homo homini homo); the term 'human' then stands for the capability to have empathy, solidarity and cooperation (in Huber 1996:118). As a relational, systemic and process category, dignity is closely related to identity as well as to integrity and congruency.

\section{The interplay between dignity, identity, integrity and congruency}

For the aim of this essay, identity can be described as a process of personal identification consisting of the interplay between: 
- Intra-processes of self-understanding and self-evaluation (Who am I?). Intra-spection as a critical assessment of ability, skill and level of responsibilities.

- Inter-processes of role-function and feedback (How do I respond and perform? Mirroring oneself within relationships: level of acceptance or rejection). Interspection as a critical evaluation of the quality of interrelated networking.

- External processes regarding norms, values, belief systems, world views and paradigms (The factor of motivation with the questions: What keeps me going? And to what do I commit myself?) Trans-spection as a critical assessment of these norms, values and belief systems that determine responsible behaviour and informed decision-making (normative framework of life).

- Contextual issues embedded in culture (What shapes my life and influences the quality of decision-making and life choices?). Interculturality: the mutual exchange between particularity within a specific context, customs and habits and the global structures that determines life on a daily basis. At stake in our global society are inter alia technology, social media and virtual reality.

'Identity', as derived from the Latin idem, indicating the same, conveys the idea of continuity. Identity presumes a continuity between the human I and behaviour; hence, the importance of congruency. Congruency happens when the self is a true reflection and portrayal of the conduct and experiences of the human I (Möller 1980:94). Congruency is about remaining faithful to oneself, communicating authenticity and truth (Heitink 1977:69). It is about the question to what extent one's belief system correlates with actions, lifestyles and behaviour.

Identity is a dynamic process. The development of identity, therefore, is not linear, but a zigzag movement between experiences of the human I and the response of the environment. The movement acts like a spiral in which experiences of life during each stage of human development play a decisive role. The factors of discontinuity and continuity, as well as acceptance and rejection, will determine the quality of the identification and therefore of identity. The level of congruency will create a sense of integrity depending on the norms and values internalised.

\section{Identity and vocation: The principle of responsibility}

The answer to the question: 'Who am I?' depends on the quality of the human reaction and on the degree and quality of human responsibility. Our basic point of departure is therefore the core principle that qualifies ethos (attitude and aptitude) in human behaviour: respondeo ergo sum. In a theological anthropology, 'identity' means that people discover that God calls them to respond to their destiny: to love God and their fellow human beings. People should therefore display the quality of their responsibility and the genuineness and sincerity of their obedience to God in the way that they love.
The principle of responsibility, which leads in turn to selfacceptance, presupposes awareness. People within a specific stage of development need to be aware that they should display real insight in the specific claim made on their personal functions during this stage. Their development and growth is determined by the extent to which they accept responsibility for the development of their potentials in life. A developmental model in a pastoral anthropology should always deal with the ethical principle of love, because it is an important director in the process of disclosing and discovering inner potentials.

We can conclude that identity as an indication of maturity and adulthood presupposes a process of maturation in which different polarities, indicating the critical challenges implied by human life, play a decisive role. Whether identity takes place and diffusion is overcome will determine the quality of adulthood: intimacy, generativity and integrity. Meaning is then interconnected to adulthood and maturity. In terms of Erikson's (1974:28) understanding of the life cycle, fidelity is the cornerstone of integrity, identity and maturity: 'Fidelity is the ability to sustain loyalties freely pledged in spite of the inevitable contradictions and confusions of value systems.' Virtue therefore determines the quality of human identity and human dignity; it describes the humanness within our being human. One could say that humanity and humanness refer to the character of our human freedom, that is, our ability to take responsibility for life and to make responsible decisions that will enhance the quality of life.

\section{Towards a pneumatological understanding of dignity and aesthetics}

To conceptualise dignity is indeed difficult. Dignity is a many layered concept:

- Dignity (dignitas) within a hierarchical paradigm points to status, position and authority.

- Dignity (dignitas) within an ethical paradigm points to equality, justice and rights within the quest for liberation.

- Dignity (dignitas) within an aesthetic paradigm points to meaning, telos (purposefulness, destiny or significance) and intimacy: the basic quest to be accepted unconditionally for who you are; the essence of the humanum.

- Dignity (dignitas) as a spiritual and theological category. In theology dignity refers to the value of human life as determined and defined by the eschatological aesthetics of a suffering God. This suffering puts God on the bottom line of life, 'below the sewer line' (Zanotelli 2002:15), within the hell of the slums. The 'ugliness' of dereliction (My God, my God why has you forsaken me?) beautifies life unconditionally, despite life under the bottom line. Spiritual aesthetics therefore determine the quality of human dignity and ethics. Garcia-Rivera (2008:177) remarks as follows: 'This em-pathos, mediated by their own distinct accounts through the beauty of the crucifix, in turn becomes, second, syn-pathos - a plea for divine sympathy with their own suffering'. 
The aesthetics of life emanate from this eschatological proposition: in Christ human beings are already a new creation; this is our Christian spiritual identity. Owing to our eschatological identity, being functions qualify knowing functions, doing functions and feeling functions This new spiritual ontology is enfleshed and exhibited in the fruit of the Spirit. Pneumatology beautifies life by means of the charisma of the Spirit and the service (diakonia) of the church. Thus, the reason why one can conclude and say that human dignity, as a theological concept in a pastoral anthropology, is primarily a pneumatological endeavour. Dignified by the Holy Spirit, life and our being human becomes beautiful. As Christians, we should then display the fruit of the Spirit and, in doing so, Christians would start to beautify life and grant others human dignity.

Aesthetics can inspire human beings to transcend the harsh conditions of inhumane living. It is most interesting to read narratives of people who survived under harsh conditions of suffering. In many cases, the factor that has kept people, robbed from their human dignity, going, was not ethics but aesthetics. In his autobiography, Moltmann (2008) comments as follows whilst referring to his concentration camp experience:

We were pushing a goods truck, and suddenly I stood in front of a blossoming cherry tree. I almost fainted with joy of it. After a long period of blindness without any interest, I saw colours again and sensed life in myself once more. Life began to blossom afresh. (p. 27)

\section{Conclusion}

\section{Towards a paradigm shift in a theological anthropology: Humanum determined by pneuma}

For the connection between aesthetics and a Christian spiritual approach to dignity, a theological anthropology needs the following paradigm shift: from incarnation theology to inhabitation theology. The praxis-question in anthropology should eventually reside in pneumatology and not in Christology. For this paradigmatic shift, the theology of the Dutch theologian A.A. van Ruler (1968) is most relevant and should be revisited. Why? Within incarnation theology the human being is nothing (homo peccator) and God is everything (sacrificial grace): Christ is mediator. Christology is about redemption. In inhabitational theology, man, the human being, is becoming 'whole' (homo aestheticus) and therefore 'everything' (humanum); human beings are not excluded in salvation (heil, sjalom), but totally incorporated (Rebel 1981:209) because the humanum is now determined by pneuma.

In terms of pneumatology, Van Ruler points to the category of 'reciprocity' (Rebel 1981:145), which means that the human will starts to correspond with the divine will according to the indwelling presence of the Spirit. The human person starts to become theonomous and therefore fully authentic and autonomous; that is, it displays the charisma of the Spirit (the soulfulness of embodied humanism).
To build in any concurrency between God and human beings is pagan idolatry (Rebel 1981:99); pneumatology rather creates a theological osmosis (Van Ruler, in Rebel 1981:85) between God and human beings. Sin is secondary, eschatological being is primary. In an Christological anthropology, the object of faith is salvation (heil = becoming whole); in a pneumatic anthropology, the object of salvation is the praxis of humanum (Rebel 1981:140). A pneumatic anthropology describes spiritual wholeness (a spiritual humanism); it determines the quality of human dignity (charisma as pneumabeauty) as well as the rights of man (aesthetic responsibility).

'Man is homo festivus and fantasia homo' (Cox 1969:11). One can even say that the attempt to formulate the Christian faith in rational categories and to define God in terms of a correct doctrine (true confession), turned the Christian faith in the direction of scientia (scientific knowledge, the positivistic knowledge of the mind), rather than to sapientia (wisdom and the devotional knowledge of the heart). As Cox (1969:10) very aptly remarked: 'Scientific method directs our attention away from the realm of fantasy and toward the manageable and the feasible.' However, man as homo aestheticus points in the direction of the sapientia of beauty: the passionate expression of redemptive grace and sensitive benevolence.

In Christian spirituality, aesthetics as the wellbeing (heil) of human beings should reckon with two important categories: doxa and charisma. Within a Christian spiritual approach dignity should be linked to habitus as a reflection of the glory of God. 'Glory (doxa) is the closest word to dignity in the New Testament' (Kraynak 2003:93). Furthermore, dignity as a spiritual category cannot avoid the notion of grace and unconditional, sacrificial love (the eschatological qualification) and the fruit of the Spirit (charisma) (the pneumatological qualification). Hence our finding that human dignity and human rights reside as spiritual categories in the fact that dignity is enfleshed in human bodies as a result of the indwelling presence of the Holy Spirit; human dignity is a matter of inhabitational theology.

Identity (characteristics), dignity (meaning and worth), ethos (habitus and pathos) and ethics (responsibility and human rights) describe an interconnected dynamics of networking relationships. This networking can be described as a hermeneutics of 'soulful human being'. An aesthetics of identity and dignity presupposes the following paradigm shift: from psycho-autonomy (self-determination) to pneuma-relationality - the intimate space of unconditional love as framed by koinonia and diakonia. In terms of this prenumatological and eschatological perspective one can claim: Happy Sindane was beautiful. Unfortunately, within the relational dynamics of life, he was never exposed to the homo aesthicus inherent to a theological anthropology. Perhaps the praxis of theology failed Happy Sindane. From a practical theological perspective I must admit: it seems that the koinonia and diakonia failed to promote the beauty of Happy Sindane. A rhino without a horn has no identity. Sindane died without a horn. His legacy: an intentional lie caused by existential unfulfilment and relational 'ugliness'. 
Instead of a provisional truth, could it perhaps be possible that a spiritual aesthetics, and the discovery of the link between identity and an eschatological understanding of homo aestheticus, could have provided a praxis framework for an existential truth in order to discover the quality of our being human?

\section{Acknowledgements}

With this essay I want to honour the contribution of my friend and colleague, Prof. Julian Müller, to the cause of Practical Theology. In terms of your endeavour to promote an eco-hermeneutic and systemic, cultural approach to practical theology, the essay is an attempt to contribute to a post-foundational discourse on the burning issues of human dignity and human rights. With reference to the challenge in a narrative approach to pastoral care and counselling, namely to assist human beings to name the issue and to externalise the problem, the notion of homo aestheticus is an attempt to articulate a different paradigm for an anthropological approach. Rather than the traditional notion of man created in the image of God (imago Dei) within the background of the Fall as starting point for a practical theological anthropology, the spiritual humanism of theopoiesis is proposed. Thanks for being a very supportive colleague.

\section{Competing interests}

The author declares that he has no financial or personal relationships that may have inappropriately influenced him in writing this article.

\section{References}

Ackermann, L., 2013, Human dignity: Lodestar for equality in South Africa, Juta \& Co., Cape Town.

Ammicht-Quinn, R., 2003, 'Whose dignity is inviolable? Human beings, machines and the discourse of dignity', in R. Ammicht-Quinn, M. Junker-Kelly \& E. Tamez (eds.) The discourse of human dignity, pp. 34-45, SCM Press, London.

Augsburger, D.W., 1986, Pastoral counseling across cultures, Westminister, Philadelphia.

Cox, H.W., 1969, The feast of fools, Harper \& Row, New York.

Crossin, J.W., 1998, What are they saying about virtue?, Paulist, New York.

Drewermann, E., 1991, Die Spirale der Angst, 4th edn., Herder, Freiburg.

Drewermann, E., 1992, Tiefenpsychologie und Exegesen, vol. 2, 3rd edn., Olten Freiburg.

Erikson, E.H., 1974, Identity, youth and crisis, 2nd edn., Faber \& Faber, London.

Fairley, E., 1983, 'Theology and practice outside the clerical paradigm', in D.S. Browning (ed.), Practical Theology, Harper \& Row, San Francisco.

Fairley, E., 2001, Faith and beauty. A theological aesthetic, Ashgate, Aldershot.

Feuerbach, L., 1904, Das Wesen des Christentums, Verlag Philipp Reclam, Leipzig.
Flory, R.W. \& Miller, D.E., 2007, 'The embodied spirituality of the post-Boomer generations', in K. Flanagan \& P.C. Jupp (eds.), A sociology of spirituality, pp. 201218, Ashgate, Aldershot.

Garcia-Rivera, A., 2008, 'On a new list of aesthetics categories', in O.V. Bycgov \& J. Fodor (eds.), Theological aesthetics after Von Balthasar, pp. 169-183, Ashgate, Aldershot.

Giorgian, G., 2007, 'Spirituality: From a religious concept to a sociological theory', in K. Flanagan \& P.C. Jupp (eds.), A sociology of spirituality, pp. 161-180, Ashgate, Aldershot.

Gräb, W., 2006, Sinnfragen. Tranasformationen des religiösen in der modernen Kultur, Gütersloher Verlagshaus, Gütersloh. PMCid:PMC1570376

Heitink, G., 1977, Pastoraat als hulpverlening: Inleiding in de pastorale theologie en psychologie, Kok, Kampen.

Huber, W., 1996, Violence. The unrelenting assault on human dignity, Fortress Press, Minneapolis.

Jackson, T.P., 2003, 'A house divided again: Sanctity vs. dignity in the induced death debates', in R.P. Kraynak \& G. Tinder (eds.), Defense of human dignity. Essays for our times, pp. 139-163, University of Notre Dame Press, Notre Dame.

Kraynak, R.P., 2003, “"Made in the image of God": The Christian view of human dignity in Protestant perspective', in R.P. Kraynak \& G. Tinder (eds.), Defense of human dignity. Essays for our times, pp. 81-118, University of Notre Dame Press, Notre Dame.

Kreeft, P., 1986, Back to virtue, Ignatius, San Francisco. PMid:3012833

MacIntyre, A., 1984, Der Verlust der Tugend. Zur moralische Krise der Gegenwart, Campus Verlag, Frankfurt. PMCid:PMC1153551

Meeks, M.D., 1984, 'Introduction', in J. Moltmann (ed.), On being human, pp. ix-xiv, SCM Press, London.

Meilaender, G.C., 1984, The theory and practice of virtue, University of Notre Dame Press, Notre Dame. PMid:6439686

Meilaender, G.C., 2009, Neither beast nor God. The dignity of the human person, New Atlantis Books, New York.

Möller, A.T., 1980, Inleiding tot die persoonlikheidsielkunde, Butterworth, Durban.

Moltmann, J., 1984, On human dignity. Political theology and ethics, SCM Press, London.

Moltmann, J., 2008, A broad place. An autobiography, Fortress Press, Minneapolis.

Mtetwa, S., 1996, 'African spirituality in the context of modernity', Bulletin for Contextual Theology in Southern Africa and Africa 3(2), 21-25.

Murphy, F.A., 2008, 'Hans Urs von Balthasar: Beauty as gateway to love', in O.V. Bycgov $\&$ J. Fodor (eds.), Theological aesthetics after Von Balthasar, pp. 5-17, Ashgate, Aldershot.

Negt, O., 2003, 'The unrepeatable: Changes in the cultural concept of dignity', in R. Ammicht-Quinn, M. Junker-Kelly \& E. Tamez (eds.), The discourse of human dignity, pp. 25-34, SCM Press, London.

Pattison, G., 2008, 'Is the time right for a theological aesthetics?', in O.V. Bycgov \& J. Fodor (eds.), Theological aesthetics after Von Balthasar, pp. 107-114, Ashgate, Aldershot.

Rebel, J., 1981, Pastoraat in pneumatologisch perspektief. Een theologisch verantwoording vanuit het denken van A.A. van Ruler, Kampen, Kok.

Rombach, H., 1987, Struktur-anthropologie. 'Der menschlich Mensch', Verlag Kar Alber, Freiburg.

Schrage, W., 1988, The ethics of the New Testament, Fortress Press, Philadelphia. PMid:3198499

Valadier, P., 2003, 'The person who lacks dignity', in R. Ammicht-Quinn, M. JunkerKelly \& E. Tamez (eds.), The discourse of human dignity, pp. 49-56, SCM Press, London.

Van Ruler, A.A., 1968, Ik geloof, Callenbach, Nijkerk.

Varga, I., 2007, 'George Simmel: Religion and spirituality', in K. Flanagan \& P.C. Jupp (eds.), A sociology of spirituality, pp. 145-160, Ashgate, Aldershot.

Witte, J.R.J., 2003, 'Between sanctity and depravity: Human dignity in Protestant perspective', in R.P. Kraynak \& G. Tinder (eds.), Defense of human dignity. Essays for our times, pp. 119-138, University of Notre Dame Press, Notre Dame.

Zanotelli, A., 2002, 'A grace freely given', in P. Francesco \& Y. Abeledo (eds.), The slums: A challenge to evangelization, pp. 13-19, Pauline Publications, Nairobi. 